\section{プロポフォールの直接的活性酸素消去能 に関する検討}

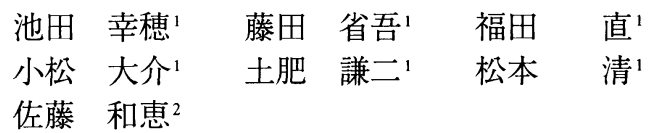

プロポフォール (2,6-diisopropylphenol ; 商品名デ イプリパン) は，わが国では1995年から臨床使用が 開始され，麻酔の導入覚醒が速やかであるなどの利 点を有していることから，その臨床使用頻度が急速 に増加している静脈麻酔剂である。頭蓋内環境, 神 経組織にも非常に良好な効果を発揮し, 脳神経外科 や脊椎脊髄外科にも非常に適した静脈麻酔剂と考え られている。また, 重症頭部外傷患者の神経集中管 理の際の鎮静剂として, その臨床的有用性が確認さ れつつある ${ }^{1-2)}$ 。本剂はフェノール基を有し，内因性 の抗酸化物質である $\alpha$-トコフェロールと構造上類似 性をもつことから，その抗酸化作用の可能性を示唆 する報告が散見する ${ }^{3.5)}$ 。今回，プロポフォールが濃 度依存性に活性酸素消去能をもっていることを，電 子スピン共鳴法（ESR）を用いて明らかにすること を目的とした。

\section{方 法:}

1）スーパーオキサイド消去能の測定；2mMhypoxanthine $50 \mu \mathrm{l}, 0.5 \mathrm{mM}$ DETAPAC (diethylenetriaminepentaacetic acid）を $20 \mu 1$, プロポフォール $(5,10,20 \mathrm{mM})$ をそれぞれ50 $\mu 1$, DMPO（5,5-dimehtyl-1-pyrroline-N-oxide）を $50 \mu 1$ 採り, xanthine oxidaseを添加，60秒後より ESRにて分析した。

2）ヒドロキシラジカル消去能の測定； $1 \mathrm{mM}$ 硫酸 第一鉄を $50 \mu 1,0.02 \mathrm{mM}$ DETAPACを $50 \mu 1$, プロ

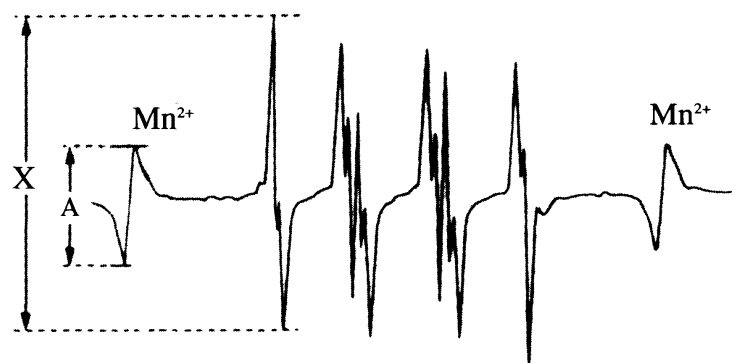

Determination of superoxide radical scavenging activity by ESR using the spin trap (DMPO) method

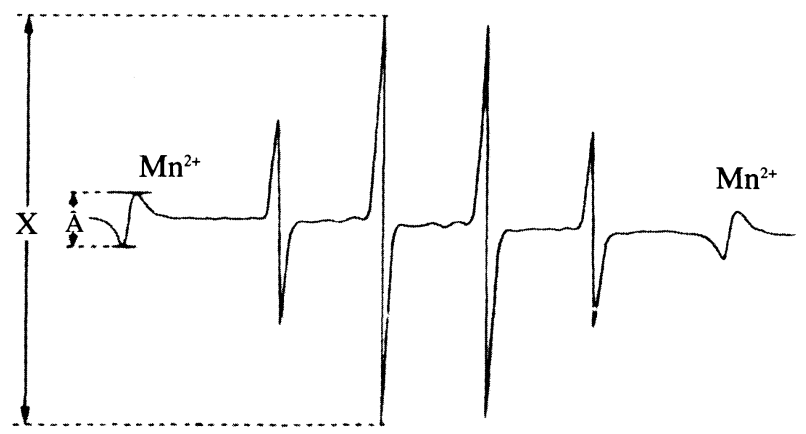

$\mathrm{X} / \mathrm{A}=$ relative signal intensity ; $\mathrm{X}=$ signal intensity ; $\mathrm{A}=$ marker intensity Determination of hydroxyl radical scavenging activity by ESR using the spin trap（DMPO） method

Fig.1. Free radical scavenging activity was measured by electron spin resonance (ESR) using 5,5-dimehtyl-1-pyrroline-N-oxide (DMPO) as a spin trap.

ポフォール $(0.14,1.4,7,14 \mathrm{mM})$ をそれぞれ $50 \mu 1$, DMPOを $20 \mu 1$ 採り, $1 \mathrm{mM}$ 過酸化水素を $30 \mu 1$ 加え た後ミキサーで擋拌後, 反応液を特殊扁平水溶セル に移し, 過酸化水素を添加, 60秒後から ESRで分析 した。上述のフリーラジカル生成系によるDMPO ス ピンアダクトのESRシグナルの強度は内部標準であ る $\mathrm{Mn}^{2+}$ のシグナルの高さと, それぞれのスペクトル の第一シグナルの高さを測定し，その比から算出し だ) (Fig. 1)。

Free radical scavenging activity of propofol

キーワード：プロポフォール (propofol), 活性酸素 (oxygen-free radical), 電子スピン共鳴 (electron spin resonance), 活性酸素 消去能 (free radical scavenging activity)

Yukio Ikeda', Shogo Fujita', Ataru Fukudal, Daisuke Komatsu', Kenji Dohi', Kiyoshi Matsumoto' and Kazue Satoh ${ }^{2}$

${ }^{1}$ 昭和大学医学部脳神経外科 2 同大学薬学部分析センター

著者連絡先：テ142-8666 品川区旗の台 1-5-8／原稿受理日：2001年2月19日（01-013） 

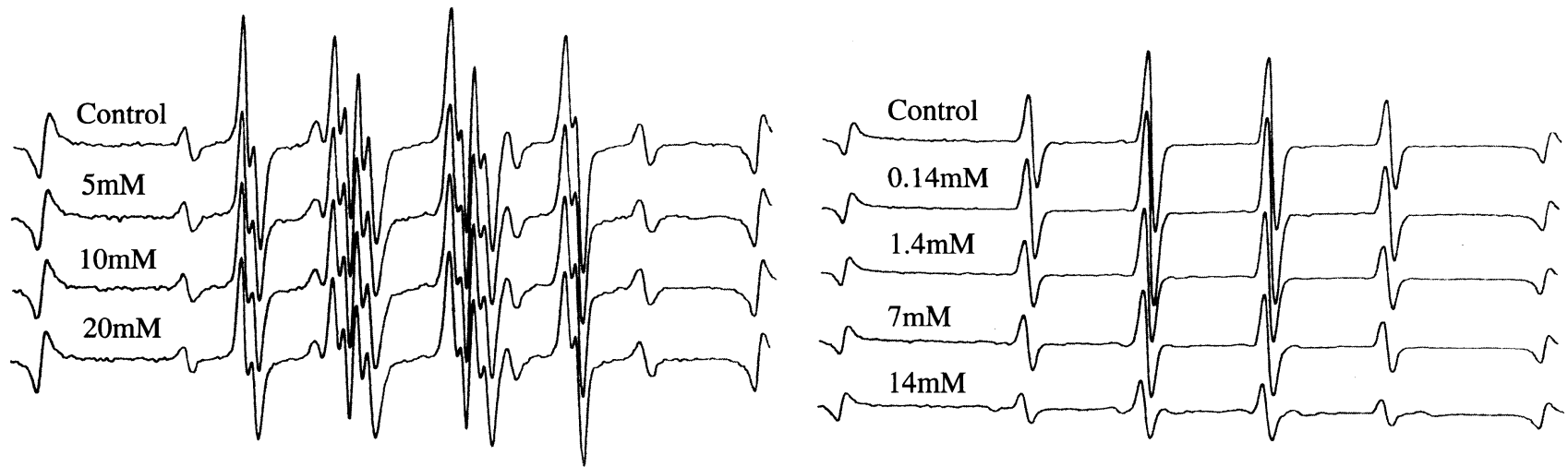

Fig. 2. Superoxide radical and hydroxyl radicalscavenging activity of propofol.

ESR showed that the formation of the superoxide radical-DMPO spin adduct was not inhibited by propofol, while the formation of the hydroxyl radical-DMPO spin adduct was significantly inhibited by propofol.

結＼cjkstart果：プロポフォールはどの濃度でもスーパー オキサイドラジカル消去能を認めなかったが, $7 \mathrm{mM}$, $14 \mathrm{mM}$ のプロポフォールで直接的なとドロキシルラ ジカル消去能を認めた（Fig. 2)。

考 察：プロポフォールはバルビタールと同様に 頭蓋内圧, 脳血流量の低下作用と脳灌流圧の維持, 脳代謝の低下などの脳保護作用を有することが指摘 されている1)。バルビタールと比べ，プロポフォー ルは投与後の組織への分布, 肝での代謝が速いこと より，作用発現が速やかで作用時間が非常に短く， 持続投与でも蓄積作用が少ないという特徴を有す る。プロポフォールが抗酸化能を有することが指摘 されているが，具体的にESRを用いてスーパーオキ サイド，ヒドロキシラジカルに対する活性酸素消去 能を直接証明した報告はない。今回の in vitroの検討 から，スーパーオキサイド消去能は認められなかっ たが，毒性の最も強いヒドロキシラジカルの直接的 活性酸素消去能の存在がESRから明らかとなった。

\section{文献}

1) Kelly DF, Goodale DB, Williams J, et al : Propofol in the treatment of moderate and severe head injury : a randomized, prospective double-blinded pilot trial. J Neurosurg $1999 ; 90: 1042-52$.

2）岡田健，山本直人，柳沢利彦，他：脳動脈瘤手術にお ける propofolによる完全麻醉（Total Intravenous Anesthesia）の有用性. 脳外速報 $2000 ； 10 ： 607-12$.

3) Aarts L, van der Hee R, Dekker I, et al : The widely used anesthetic agent propofol can replace $\alpha$-tocopherol as an antioxidant. FEBS Lett $1995 ; 357: 83-5$.

4) Murphy PG, Benett JR, Myers DS, et al : The effect of propofol anaesthesia on free radical-induced lipid peroxidation in rat liver microsomes. Eur J Anaesth 1993 ; $10: 261-6$.

5) Kahraman S, Dermiryurek AT : Propofol is a peroxynitrite scavenger. Anesth Analg $1997 ; 84: 1127-9$.

6）白戸真実：顎囊胞の洗浄液打よび内溶液成分によるフ リーラジカル生成に対する効果. 磁気共鳴と医学 $1991 ; 2: 147-51$. 